\title{
Determinants of Entrepreneurial Intention among Engineering Students Based on Structural Equation Modeling
}

\author{
Diana Arango-Botero ${ }^{1 *}$, Martha Luz Benjumea Arias², Mauricio Hincapié \\ Montoya $^{3}$ and Alejandro Valencia-Arias ${ }^{4,5 *}$
}

${ }^{1}$ Department of Management Sciences, Instituto Tecnológico Metropolitano, Medellín 050013, Antioquia, Colombia

${ }^{2}$ Department of Finance, Instituto Tecnológico Metropolitano, Medellín 050013, Antioquia, Colombia ${ }^{3}$ Corporación Universitaria Americana, Medellín 050013, Antioquia, Colombia.

${ }^{4}$ Universidad Católica Los Ángeles de Chimbote, Instituto de Investigación, Chimbote 02804, Perú

${ }^{5}$ Corporación Universitaria Americana, Medellín 050013, Antioquia, Colombia

\begin{abstract}
Entrepreneurial intention models are widely accepted in university contexts in developed countries; however, more robust studies in emerging economies are needed. With the aim of filling this gap, this work analyzes the influence of subjective norms, behavioral beliefs, attitudes, and entrepreneurial behavior on the entrepreneurial intention of college students. Structural equation modeling was implemented by means of a self-administered questionnaire that was answered by 636 undergraduate engineering students in Medellín, Colombia. According to the findings, both attitude and entrepreneurial behavior have a positive effect on entrepreneurial intention. Nevertheless, no evidence was found to confirm that subjective norms affected entrepreneurial intention, i.e., that other people's

ARTICLE INFO

Article history:

Received: 16 August 2019

Accepted: 18 June 2020

Published: 25 December 2020

DOI: https://doi.org/10.47836/pjssh.28.4.08

E-mail addresses:

dianaarangob@itm.edu.co (Diana Arango-Botero) opinions were important to individuals when they decided to start a new venture. By investigating the entrepreneurial intention of college students, better strategies can be adopted to promote venture creation among this population group, focusing efforts on the variables that presented the strongest relationships in the model proposed in this study.
\end{abstract}

marthabenjumea@itm.edu.co (Martha Luz Benjumea Arias) emhincapie@americana.edu.co (Mauricio Hincapié Montoya) javalenciar@gmail.com (Alejandro Valencia-Arias) *Corresponding author
Keywords: Attitude, behavioral beliefs, college students, engineering, entrepreneurship, SEM 


\section{INTRODUCTION}

In recent decades, entrepreneurship has been consolidated as one of the fastest-growing research fields in terms of quantity as well as sophistication (Cefis \& Marsili, 2011; Nueno, 1994; Pulgarin \& Cardona, 2016; Veciana, 1999; Vergés et al., 2003). This is because the creation of new ventures is considered one of the most important ways to generate employment and a driver of economic growth, innovation, and social development (Acs \& Szerb, 2010; Song et al., 2008). Those benefits are particularly relevant to tackle current global issues, such as high unemployment rates and the constant increase in the number of graduates, out of which only a low percentage can join the formal sector (Adekiya \& Ibrahim, 2016). Therefore, studying the origin of the entrepreneurial process and its causes is the starting point in order to implement strategic promotion policies that have a positive effect on economic growth (Bergh et al., 2011; Lee et al., 2011; Sebora \& Theerapatvong, 2010; Van Riel et al., 2011).

Entrepreneurial intention is considered a prerequisite to the decision of starting a business (Soria et al., 2016) because it is one of the primary and most significant predictors of entrepreneurial behavior (Fang \& Chen, 2019; Guzmán \& Guzmán, 2012; Shamsudin et al., 2017; Torres et al., 2018). This idea is supported by several authors such as Gailly and Fayolle (2004), Kolvereid (1996), and Lee and Wong (2004), who claimed that entrepreneurial intentions were the first step in the course of the venture creation processes (sometimes in the long term). Similarly, entrepreneurial intentions create the initial strategic structure of new organizations and are essential to develop new ventures (Bird, 1988; Echeverri-Sánchez et al., 2018). However, several barriers may discourage or reduce entrepreneurial intention (Bates, 1995, Lien et al., 2002; Hernández-López et al., 2018) administrative difficulties, banks' unwillingness to fund new projects, and an unfavorable cultural environment. All of them have been extensively studied by researchers such as Carayannis et al. (2003) and Schmutzler et al. (2019).

Several studies have contributed to the dissemination and implementation of entrepreneurial intention models, thus confirming their applicability and progress in different contexts (including attitudes and some specific personality traits as determiners of said intentions) and highlighting the stability of the field (Liñán \& Chen, 2009; Shepherd et al., 2015). For instance, in the academic field, entrepreneurial studies have explored the emergence of new organizations, conditions to generate innovation, and factors that lead to the promotion of venture creation (Ayalew, 2020; Lichtenstein, 2016). In addition, many of these studies confirm that the university context plays a key role in students' entrepreneurial intentions (Ordoñez et al., 2017). Therefore, great efforts are currently being made in terms of educational policies to provide students with more information regarding 
entrepreneurship issues, seeking to increase coverage and guaranteeing access to Higher Education Institutions for more people.

The Colombian Government has entrepreneurship programs and public policies that seek to support entrepreneurs who have the initiative to create new businesses with a technological focus. However, few studies have analyzed and identified the entrepreneurial intentions of university students in undergraduate programs with a technological focus, such as engineering (Eyel \& Durmaz, 2019; Galleguillos-Cortés et al., 2019), who represents one of the main groups in society that policies to promote technology-based entrepreneurship can target.

Therefore, this study aims to close this gap and examine the entrepreneurial intention of university students by answering the following research question: What are the determining factors of entrepreneurial intention in engineering students?

To answer this question, multiple models have been developed in the field of entrepreneurial research (Guzmán \& Guzmán, 2012), such as the Theory of Planned Behavior (TPB) and Shapero's model of the entrepreneurial event (Botsaris \& Vamvaka, 2012), which reveal why many entrepreneurs decide whether or not to start a venture (Krueger \& Carsrud, 1993). In accordance with said models, any entrepreneurial behavior is preceded by the intention to adopt said behavior, and those conducts can be promoted to have a positive effect on entrepreneurial intentions and, indirectly, on venture creation and entrepreneurial behavior in a given area (Guzmán \& Guzmán, 2012). Nevertheless, Ajzen's Theory of Planned Behavior (1991) is the dominant model to analyze entrepreneurial intention (Fayolle \& Liñán, 2014; Munir et al., 2019); for that reason, it was selected to carry out the present study. First, this study begins with a conceptual framework and with the establishment of five hypotheses to connect different factors that may influence entrepreneurial intention based on reports or information provided by different authors. The quantitative method adopted in this work includes a selfadministered questionnaire that collected information from 636 undergraduate engineering students in Medellín, Colombia. The data were later evaluated and fitted, and an instrument was used to conduct the statistical analysis. Finally, this work presents the results obtained from the structural evaluation and the comparison of hypotheses in order to discuss the content and the findings of each hypothesis.

\section{CONCEPTUAL FRAMEWORK}

This work examines the influence of five different factors on the entrepreneurial intention of college students (Table 1).

In the context of entrepreneurship, behavioral beliefs can be defined as the expected advantages and disadvantages of creating a venture (Marcati et al., 2008), which are analyzed by individuals to establish if they are prepared to undertake the related action (Segal et al., 2005). For that reason, such behavioral beliefs influence 
Table 1

Constructs involved in this study

\begin{tabular}{|c|c|c|}
\hline Constructs & Definition & Reference \\
\hline $\begin{array}{l}\text { Behavioral } \\
\text { beliefs }\end{array}$ & $\begin{array}{l}\text { Mental associations between an object or behavior } \\
\text { and its perceived attributes. }\end{array}$ & $\begin{array}{l}\text { Marcati et al. } \\
(2008)\end{array}$ \\
\hline $\begin{array}{l}\text { Personal } \\
\text { attitudes }\end{array}$ & $\begin{array}{l}\text { Learned predisposition to respond in a consistently } \\
\text { favorable or unfavorable manner to a given object. }\end{array}$ & $\begin{array}{l}\text { Ajzen and } \\
\text { Fishbein (1977) }\end{array}$ \\
\hline $\begin{array}{l}\text { Normative } \\
\text { beliefs }\end{array}$ & $\begin{array}{l}\text { Results individuals believe will be produced by } \\
\text { adopting a behavior, weighted by the individual } \\
\text { motivation to meet subjective standards. }\end{array}$ & $\begin{array}{l}\text { Chorlton et al. } \\
(2012)\end{array}$ \\
\hline $\begin{array}{l}\text { Subjective } \\
\text { rules }\end{array}$ & $\begin{array}{l}\text { Individuals' motivations to behave according to what } \\
\text { an individual or a group think. }\end{array}$ & Pee et al. (2008) \\
\hline $\begin{array}{l}\text { Entrepreneurial } \\
\text { behavior }\end{array}$ & $\begin{array}{l}\text { The search for opportunities without taking into } \\
\text { account the resources currently under control. }\end{array}$ & Erikson (2002) \\
\hline $\begin{array}{l}\text { Entrepreneurial } \\
\text { intention }\end{array}$ & $\begin{array}{l}\text { Intentionality is a state of mind that directs a person's } \\
\text { attention (and therefore experience and action) toward } \\
\text { a specific object (goal) or a path to achieve something } \\
\text { (means). This entrepreneurial intention, specifically, } \\
\text { can be interpreted as "a state of mind in terms of } \\
\text { starting a new business". }\end{array}$ & $\begin{array}{l}\text { Bird (1988) and } \\
\text { Sondari (2014) }\end{array}$ \\
\hline
\end{tabular}

attitudes toward entrepreneurship because the social environment where individuals are educated contributes to develop their attitudes (Tarkiainen \& Sundqvist, 2005; Vamvaka et al., 2020). Therefore, the first hypothesis is introduced:

H1: Behavioral beliefs have a positive influence on attitudes toward entrepreneurship.

Normative beliefs and subjective norms are two different concepts. The former refers to the results an individual thinks will be produced by adopting a behavior, conditioned by the individual's motivation to conform to subjective norms (Chorlton et al., 2012); the latter describes the motivation a person has to behave in accordance with what an individual or group thinks he or she should do (Pee et al., 2008). Nevertheless, the two ideas are closely related. According to Marcati et al. (2008), normative beliefs are about who would approve or reject a given behavior; in addition, they are among the main individual and environmental characteristics that influence students' entrepreneurial intention (Duong et al., 2020). Thus, the second hypothesis emerges:

H2: Normative beliefs have a positive influence on subjective norms.

As a consequence, individuals perceive a high probability that their attitudes will lead to adequate venture creation. Ajzen 
(1991) claimed that attitude toward behavior in the context of entrepreneurship was the first antecedent of entrepreneurial intention. This idea supports the findings of Marques et al. (2012), who proposed the existence of a highly significant positive relationship between attitude and intention. In addition, several studies have shown that attitudes are the most influential variable in entrepreneurial intention (Lechuga et al., 2020).

Hypothesis 3 is thus proposed:

H3: Attitudes have a positive influence on entrepreneurial intention.

According to Ajzen (1991), the attitudes in the previous statement refer to the degree to which individuals perceive the attraction of the conduct under analysis. A favorable attitude toward said behavior is related to the individual's belief that it will lead to a high probability of positive results.

As mentioned in the justification of $\mathrm{H} 2$, subjective norms are one of the main determinants of an individual's intention because the social environment and culture directly affect people's behavior (Lechuga et a1., 2020). An example of this is the context of Latin American students, where three groups of people have been identified to influence the most a young person's motivation to create a venture: friends, relatives and, in general, parents (Bolaños, 2006; Díez-Echavarría et al., 2019). Hence, Hypothesis 4 is formulated:

H4: Subjective norms have a positive influence on entrepreneurial intention.
Entrepreneurial behavior can be defined as "the search for opportunities disregard the resources currently under control" (Erikson, 2002, p. 278). According to van Dam et al. (2010), such behavior implies managing resources to make the most of the identified opportunities. Interesting findings regarding this definition have been reported in the literature. For example, people who have skills to start a venue will positively affect their subjective norms, thus favoring an entrepreneurial behavior, and the more individuals' social circles value and support entrepreneurship, the greater the skills they feel they have to start a venue, thus increasing their intention (Liñán, 2008). This is confirmed by Bolaños (2006) and DíezEchavarría et al. (2020), who highlighted how influential it was for individuals that their immediate family, friends, and those who were important to them show their support to the entrepreneurial activity, as it helped to trigger an entrepreneurial behavior that resulted in the following hypothesis:

H5: Entrepreneurial behavior has a positive influence on entrepreneurial intention.

\section{METHOD}

In this work, a cross-sectional descriptive field study was conducted adopting a quantitative method through a selfadministered questionnaire (the instrument to collect information). Such type of questionnaire was implemented due to its low cost, convenience, briefness, and easy preparation (Suárez et al., 2009). The sample comprised 636 undergraduate engineering students in Medellin, Colombia (Table 2). 
Before the information was gathered, a pilot and users' comprehension of the structure test was carried out to evaluate the clarity and items in the questionnaire.

Table 2

Characteristics of participants

\begin{tabular}{ll}
\hline Field of the engineering undergraduate program & Percentage of the sample \\
\hline Mines, Oil, Geology & $15 \%$ \\
Electricity, Electronics & $8 \%$ \\
Systems, Telecommunications, Civil & $39 \%$ \\
Administration, Finance, Industry, Control & $25 \%$ \\
Chemistry, Physics, Mechanics & $9 \%$ \\
Biology, Environment & $3 \%$ \\
Total & $100 \%$ \\
& \\
Semesters Enrolled & Percentage \\
Up to 4 & $40 \%$ \\
Between 5 and 7 & $27 \%$ \\
8 or more & $33 \%$ \\
Total & $100 \%$ \\
Age & \\
Up to 22 years & Percentage \\
$23-29$ & $62 \%$ \\
30 or more & $31 \%$ \\
Total & $7 \%$ \\
\hline
\end{tabular}

The final questionnaire measured 6 attitudes (PATs), from the study by Liñan constructs, each with 3 items (evaluated and Chen (2009); and the ones about on a Likert scale with 5 answer options), Behavioral beliefs (BEH_BEL) were based for a total of 18 questions. The questions on Liñan and Chen (2009). In addition, regarding the Entrepreneurial intention Entrepreneurial behavior (ENTRE) was (INTENTION) construct were adapted from measured as in Naktiyok et al. (2010). Liñán et al. (2011); those about Personal Normative beliefs (NOR_BEL) were 
measured as in Iakovleva and Kolvereid (2009). Finally, Subjective norms (NORMS) were measured using questions adapted from Iakovleva and Kolvereid (2009). The final version of the questionnaire can be found in Appendix 1.

The sampling in this study was nonprobabilistic in terms of two inclusion criteria: participants should (1) be currently enrolled in an engineering program and (2) live in Medellin. Different engineering programs in the city were visited over a period of 3 months. We had the authorization of the universities in order to take a moment in class to explain the information and have each student autonomously answer the survey. The information was gathered from 23 academic engineering programs in the city. We collected 657 surveys, out of which 21 were discarded because all their fields were not filled out or their information was incorrect. Finally, the data were tabulated, and the statistical analysis was conducted.

The method implemented in this study to analyze the results, Structural Equation Modeling, comprises two parts: a measurement model and a structural model. For that reason, before the hypotheses proposed in this study are compared, they must be confirmed. The statistical analyses were conducted using the Psych and Lavaan packages of R software.

\section{RESULTS}

\section{Evaluation of the Measurement Model}

The convergent validity, discriminant validity, and reliability of the internal consistency of the instrument were verified for the statistical validation of the model.

Two indicators were used for convergent validity: the Kaiser-Meyer-Olkin (KMO) test $(>0.5)$ and Bartlett's test of sphericity $(p \rightarrow 0)$. All the variables intersected the cut-off points. The standardized factor loadings were analyzed to test convergent validity (Table 3 ). An item is considered to converge to the construct it measures if its factor loading is above 0.5 (Bagozzi \& Yi, 1988) and the average of the loadings of the questions of the construct is greater than 0.7 (Hair et al., 2010).

Table 3

Average and standardized factor loadings of the constructs

\begin{tabular}{llll}
\hline Construct & Item & Factor Loadings & Average \\
\hline INTENTION & AJ1 & 0.729 & 0.736 \\
& AJ2 & 0.792 & \\
& AJ3 & 0.687 & \\
\hline
\end{tabular}


Table 3 (Continued)

\begin{tabular}{llll}
\hline Construct & Item & Factor Loadings & Average \\
\hline PATs & C1 & 0.813 & 0.762 \\
& C2 & 0.738 & \\
BEH_BEL & C3 & 0.734 & 0.723 \\
& B1 & 0.743 & \\
ENTRE & B2 & 0.607 & \\
& B3 & 0.819 & 0.745 \\
& I1 & 0.716 & \\
NOR_BEL & I2 & 0.815 & 0.78 \\
& I3 & 0.704 & \\
NORMS & D1 & 0.73 & 0.76 \\
& D2 & 0.858 & \\
& D3 & 0.753 & \\
\hline
\end{tabular}

Additionally, to verify the discriminant validity of our model, we calculated confidence interval estimates of the correlations between its pairs of constructs. According to Anderson and Gerbing (1988), the fact that such intervals do not contain a value of 1 is a sign of discriminant validity. A second method is to verify that the average variance extracted (AVE) for every construct exceeds the square of the correlation between each pair of constructs (Fornell \& Larcker, 1981). Table 4 presents the results described above. The diagonal indicates the square root of the average variance extracted (Table 5); under it, the confidence interval of the correlation between constructs; above it, the estimated correlation between them. It can be seen from Table 4 that all the constructs passed the two discriminant validity tests.

After the convergent and discriminant validations, the reliability or internal consistency of the measurement was evaluated with Cronbach's coefficient. A reliability value of around 0.7 is assumed to be adequate (Nunnally \& Bernstein, 1994). Additionally, the reliability analysis can be complemented with the calculation of the Compound Reliability (CR) and Average Variance Extracted (AVE) of each construct, which is expected to be above 0.5. Table 5 lists the values of Cronbach's alpha, Compound Reliability (CR), and Average Variance Extracted (AVE) of each construct; all of them are satisfactory. 
Table 4

Discriminant validity of the measurement model

\begin{tabular}{lllllll}
\hline & INTENTION & PATs & BEH_BEL & ENTRE & NOR_BEL & NORMS \\
\hline INTENTION & 0.74 & 0.52 & 0.39 & 0.48 & 0.5 & 0.15 \\
PATs & {$[0.46,0.57]$} & 0.76 & 0.48 & 0.39 & 0.4 & 0.16 \\
BEH_BEL & {$[0.32,0.45]$} & {$[0.42,0.54]$} & 0.73 & 0.42 & 0.43 & 0.23 \\
ENTRE & {$[0.42,0.54]$} & {$[0.32,0.45]$} & {$[0.35,0.48]$} & 0.75 & 0.43 & 0.19 \\
NOR_BEL & {$[0.43,0.55]$} & {$[0.33,0.46]$} & {$[0.36,0.49]$} & {$[0.36,0.49]$} & 0.78 & 0.25 \\
NORMS & {$[0.08,0.23]$} & {$[0.08,0.23]$} & {$[0.16,0.31]$} & {$[0.12,0.27]$} & {$[0.17,0.32]$} & 0.76 \\
\hline
\end{tabular}

Table 5

Reliability indices

\begin{tabular}{llll}
\hline Construct & Cronbach's Alpha & CR & AVE \\
\hline INTENTION & 0.914 & 0.78 & 0.54 \\
PATs & 0.776 & 0.81 & 0.58 \\
BEH_BEL & 0.769 & 0.77 & 0.53 \\
ENTRE & 0.847 & 0.79 & 0.56 \\
NOR_BEL & 0.904 & 0.82 & 0.61 \\
NORMS & 0.888 & 0.81 & 0.58 \\
\hline
\end{tabular}

Note: CR: Compound Reliability. AVE: Average Variance Extracted.

Evaluation of the Structural Model and Comparison of Hypotheses

The second part of SEM is the structural component, which evaluates the relationships between different constructs or latent variables (Figure 1).

Before comparing the hypotheses established in Figure 1, their compliance with some indices proposed in the literature must be verified in terms of evaluating the goodness of fit of the proposed model with the collected data. Authors such as $\mathrm{Hu}$ and Bentler (1999) claimed that values under 0.06 in the RMSEA index and below 0.08 in SRMR suggested a good fit. According to them, another sign of good fit is a value less 


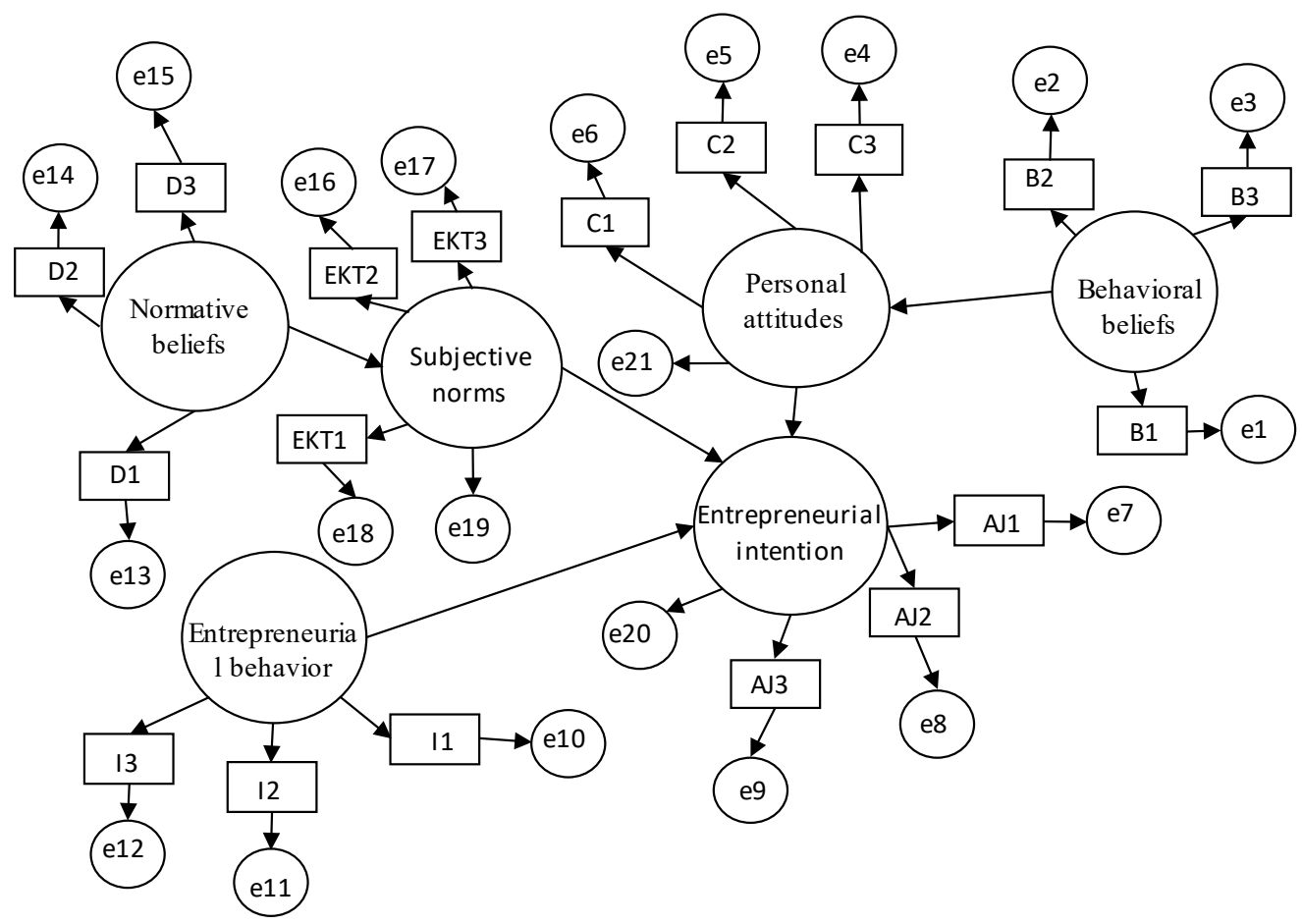

Figure 1. Entrepreneurial intention model

than 3 in the quotient between the statistic of $\chi^{2}$ and its degrees of freedom $\left(\chi^{2} / d f<3\right)$. Hair et al. (2010), in turn, held that values exceeding 0.9 in the CFI and TLI indices reflected a good fit. Such indices were calculated in Table 6 using the SEM function of the Lavaan package (Rosseel, 2012) in R software (The R Core Team, 2016).

In accordance with the values of the indices of the initial model in Figure 1 (listed in the third column of Table 6), none of the measures reached its corresponding threshold; as a result, some correlations between the constructs behavioral beliefs, normative beliefs, and entrepreneurial behavior were introduced. The values of the indices in the modified model meet their corresponding thresholds. The structural model with the suggested modifications is thus validated.

Table 7 presents the estimates of the regression coefficients and the p-values of the relationships in the hypotheses. Four out of the five hypotheses examined in this work were supported at a significance level of 0.001 . The hypothesis that proposes a positive influence of subjective norms on entrepreneurial intention is the only exception (valor $\mathrm{p}=0.141$ ). Additionally, the standardized coefficients were calculated (column 5) to compare the strength of the relationships. As a result, the strongest 
relationship was the positive influence of the variable Behavioral beliefs on Personal attitudes, with an expected change of 0.93 units in the latter when there was a variation of one standard deviation in the former.

Table 6

Measures of goodness of fit of the models

\begin{tabular}{llllll}
\hline & & \multicolumn{2}{c}{ Initial model } & \multicolumn{2}{c}{ Modified model } \\
\cline { 3 - 6 } Index & Threshold & $\begin{array}{l}\text { Measured } \\
\text { value }\end{array}$ & Decision & $\begin{array}{l}\text { Measured } \\
\text { value }\end{array}$ & Decision \\
\hline RMSEA & $\leq 0.06$ & 0.092 & Not met & 0.055 & Met \\
SRMR & $<0.08$ & 0.182 & Not met & 0.046 & Met \\
$\chi^{2} / d f$ & $<3$ & 6.24 & Not met & 2.86 & Met \\
CFI & $>0.9$ & 0.808 & Not met & 0.933 & Met \\
TLI & $>0.9$ & 0.774 & Not met & 0.920 & Met \\
\hline
\end{tabular}

Note: RMSEA: Root mean square error of approximation. SRMR: Standardised Root Mean Residual. CFI: Comparative Fit Index. TLI: Tucker-Lewis Index. df: degree freedom.

Table 7

Estimates and hypothesis tests

\begin{tabular}{|c|c|c|c|c|c|c|c|}
\hline & $\begin{array}{l}\text { Independent } \\
\text { variable }\end{array}$ & $\begin{array}{l}\text { Dependent } \\
\text { variable }\end{array}$ & Coef. & $\begin{array}{l}\text { Stand. } \\
\text { Coef. }\end{array}$ & t-value & $\mathrm{P}(>|\mathrm{t}|)$ & Hypothesis \\
\hline $\mathrm{H} 1$ & $\begin{array}{l}\text { Behavioral } \\
\text { beliefs }\end{array}$ & $\begin{array}{l}\text { Personal } \\
\text { attitudes }\end{array}$ & 2.534 & 0.93 & 3.433 & 0.001 & Supported \\
\hline $\mathrm{H} 2$ & $\begin{array}{l}\text { Normative } \\
\text { beliefs }\end{array}$ & $\begin{array}{l}\text { Subjective } \\
\text { norms }\end{array}$ & 0.383 & 0.358 & 7.226 & 0 & Supported \\
\hline H3 & $\begin{array}{l}\text { Personal } \\
\text { attitudes }\end{array}$ & $\begin{array}{l}\text { Entrepreneurial } \\
\text { intention }\end{array}$ & 0.373 & 0.522 & 3.405 & 0.001 & Supported \\
\hline $\mathrm{H} 4$ & $\begin{array}{l}\text { Subjective } \\
\text { norms }\end{array}$ & $\begin{array}{l}\text { Entrepreneurial } \\
\text { intention }\end{array}$ & -0.107 & -0.059 & -1.472 & 0.141 & $\begin{array}{l}\text { Not } \\
\text { supported }\end{array}$ \\
\hline H5 & $\begin{array}{l}\text { Entrepreneurial } \\
\text { behavior }\end{array}$ & $\begin{array}{l}\text { Entrepreneurial } \\
\text { intention }\end{array}$ & 0.807 & 0.414 & 4.042 & 0 & Supported \\
\hline
\end{tabular}




\section{DISCUSSION}

$\mathrm{H} 1$, the positive influence of behavioral beliefs on attitudes, is related to individuals' certainty that some people or even institutions (that are relevant to them) expect them to exhibit a given behavior (Hirsch \& Pérez, 2005). In the context of entrepreneurship, behavioral beliefs can be understood as the advantages and disadvantages that can be expected from starting a venture (Marcati et al., 2008). Among the main advantages that establish a strong relationship between behavioral beliefs and entrepreneurial attitudes, an entrepreneurial lifestyle stands out. Such lifestyle is associated with autonomy, financial independence, more economic compensation, risk-taking, and the desire to achieve higher personal and professional objectives (Henderson, 2002; as cited in Marcketti et al., 2006; Ismail \& Zain, 2015).

Additionally, individuals can choose from several behavioral options. However, to make that decision, they analyze the degree of control they have over said behaviors (Krueger et al., 2000; Van Gelderen et al., 2015) and which one will produce better results, being aware that some behaviors bring along great difficulties that will require a great commitment from them. At this point, beliefs about their behavior influence their attitudes because they directly help the individual to feel prepared or not to perform the related action (Segal et al., 2005). For that reason, said behavioral beliefs have an impact on attitudes toward entrepreneurship because the social environment where individuals are educated contributes to develop their attitude (Tarkiainen \& Sundqvist, 2005).

$\mathrm{H} 2$ refers to the positive influence of normative beliefs on subjective norms, and its Somers' D reached 0.138. Regarding this result, subjective norms are directly related to normative beliefs because they stem from the influences of the people who are important for the individual. The two concepts are not the same because normative beliefs refer to a specific individual or group, while subjective norms generally come from people who are considered significant (Souitaris et al., 2007).

$\mathrm{H} 3$, the positive influence of attitudes on entrepreneurial intention, is an idea confirmed by several authors, such as Herrington et al. (2011), Peterman and Kennedy (2003), and Rae (2010). Furthermore, this relationship is a logical assumption in the context of this work because the educational environment reinforces positive personal attitudes toward entrepreneurship (Zeng et al., 2011). Specifically, extensive knowledge of venture creation generates better personal attitudes toward entrepreneurship (Tshikovhi \& Shambare, 2015). Among the personal attitudes associated with a higher likelihood of starting a new venture, factors such as creativity and innovation capacity have been found to be the most influential in encouraging entrepreneurship (Hattab, 2014).

Moreover, in general, individuals perceive a high probability that their attitudes will lead to adequate venture creation. This is in line with the findings of Marques et 
al. (2012), who proposed the existence of a positive, highly significant relationship between attitude and intention. One of the factors that can explain this attitude is the personal satisfaction generated by the entrepreneurial lifestyle, as it is associated with feelings of personal growth, the achievement of goals, and personal success (Marcketti et al., 2006). Such results are positive because a favorable personal attitude helps individuals to focus on their venture creation objective (Bird, 1988; Krueger \& Carsrud, 1993; cited in Moriano et al., 2011).

$\mathrm{H} 4$ proposes a positive influence of subjective norms on entrepreneurial intention. The term subjective norms in it refers to the perception of the set of norms there is in a society or an individual's environment, which generally tends to vary from person to person even in the same environment; for that reason, such norms are said to be individual perceptions of values, beliefs, and behaviors. Usually, their influence is more significant or respected when they are adopted by people who are very important for the individual (Basu \& Virick, 2007).

Due to the significance of subjective norms for entrepreneurial intention, they can be influenced by entrepreneurship programs (Basu \& Virick, 2007; Souitaris et al., 2007). This is confirmed by Souitaris et al. (2007), who compared the subjective norms of individuals participating and not participating in entrepreneurship programs. They found that those who were trained in entrepreneurship perceived more positive subjective norms. This may be one of the reasons why this hypothesis was discarded in the present study since only $9 \%$ of the respondents were participating in training programs for business creation. Therefore, they do not have constant interaction with entrepreneurial people in their social environment. Additionally, students are at an age where they want to have more autonomy in their decisions; as a result, they attach less importance to the opinions of their immediate environment, in contrast to professionals, who can consider their social context to be more relevant.

H5 describes the positive influence of entrepreneurial behavior on entrepreneurial intention. This can be the case because participants are pursuing undergraduate studies which, according to Torres et al. (2018), creates more opportunities for support when a new venture is created. As a result, individuals who receive training or support have more ambitious objectives and visions than those who do not. In that regard, the role of the economic and business environment is highlighted as one of the factors that influence entrepreneurial intention because social, economic, and cultural differences result in dissimilar entrepreneurial behaviors (Bosma et al., 2008; as cited in Moriano et al., 2011).

Finally, a limitation of this study was that it included engineering students in only one city. Future research should compare several Latin American cities with similar demographic and cultural conditions. Additionally, a non-probabilistic sampling becomes a limitation for the 
generalization of the results; therefore, stratified random sampling should be implemented in future studies. In addition, the fact that this is a cross-sectional study does not allow us to observe the evolution of entrepreneurial intention throughout the university education process, which makes it difficult to identify the variables that intervene in the strengthening of business creation intention in college.

\section{CONCLUSIONS}

This article contributes to the understanding of the entrepreneurial intention of engineering students in the context of an emerging economy. The hypotheses we proposed are supported by positive relationships between behavioral beliefs and personal attitudes (H1), personal attitudes and entrepreneurial intention (H3), and entrepreneurial behavior and entrepreneurial intention (H5). These results will allow centers for entrepreneurial education at universities that offer engineering programs to take measures so that students have more entrepreneurial experiences that strengthen their entrepreneurial behavior and orient their training programs to strengthen business creation attitudesthrough exposure to successful practices and a greater awareness of the creation of technology-based companies in the market.

The strongest relationship in this study was found between behavioral beliefs and personal attitudes (with a standard coefficient of 0.93). This shows that, if there is a positive perception of the advantages of creating a company, individuals will have a better attitude towards entrepreneurship. From this perspective, it should be taken into account that respondents may have several behavioral options to choose from. Therefore, their decision may depend on how much control they have over these behaviors and, in the case of entrepreneurship, on the fact that engineering students may or may not feel qualified to create a company. Furthermore, individuals' social, cultural, and educational environment imposes the conditions for their attitude.

The moderate relationship between entrepreneurial behavior and entrepreneurial intention indicates that entrepreneurial behavior influences the development of certain capacities and abilities for business creation, allowing individuals to develop a personal position in relation to entrepreneurship. Additionally, entrepreneurial behavior is encouraged if the social and educational context of entrepreneurial students provides them with opportunities and resources. When a decision regarding a new venture is being made, individuals are highly influenced by the feasibility of the project because it is essential to consider the risks or difficulties said choice can bring along. Based on their analysis, individuals can establish if they are prepared or not to take on responsibility.

People around individuals willing to start a venture play an important role because the motivation and approval they express is decisive for said individuals to develop their ideas. Nevertheless, it is relevant to analyze what other variables 
influence this factor because the hypothesis test rejected that alternative.

Personal attitudes toward entrepreneurship are decisive as well because they enable a clear focus on the actions to be undertaken to adequately create a venture; that is, displaying said attitudes may mean that people can achieve their goals.

The positive influence of subjective norms on entrepreneurial intention can also be explained because the social and cultural environments that surround individuals directly shape their behavior, more so if said influences come from people important to them (usually friends, parents, and other relatives).

The search for opportunities, i.e., entrepreneurial behavior, surrounded by a society that values and supports entrepreneurship will make people feel more confident and have better skills, thus increasing their intention to create new ventures.

Future research should incorporate new variables into the model proposed in this study, such as risk tolerance, entrepreneurial experience, and perceived self-efficacy, which have shown greater relevance in recent years. In addition, a longitudinal study should examine the university population in order to determine their entrepreneurial intention when they start their higher education studies as well as the evolution of said intention using two surveys, one in the middle and one at the end of their academic programs. This would allow scholars to clearly follow the influence of university education on each of the variables involved in entrepreneurial intention.

\section{ACKNOWLEDGEMENT}

We would like to thank Instituto Tecnologico Metropolitano (Medellin) and Corporación Universitaria Americana for the financial support for this research.

\section{REFERENCES}

Acs, Z. J., \& Szerb, L. (2010). The global entrepreneurship and development index. In Opening up innovation: Strategy, organization and technology. London, England: Imperial College London Business School.

Adekiya, A. A., \& Ibrahim, F. (2016). Entrepreneurship intention among students. The antecedent role of culture and entrepreneurship training and development. The International Journal of Management Education, 14(2), 116-132. doi:10.1016/j.ijme.2016.03.001

Ajzen, I. (1991). The theory of planned behavior. Organizational Behavior and Human Decision Processes, 50(2), 179-211. doi: 10.1016/07495978(91)90020-T

Ajzen, I., \& Fishbein, M. (1977). Attitude-behavior relations: A theoretical analysis and review of empirical research. Psychological Bulletin, 84(5), 888-918. doi: 10.1037/0033-2909.84.5.888

Anderson, J. C., \& Gerbing, D. W. (1988). Structural equation modeling in practice: A review and recommended two-step approach. Psychological Bulletin, 103(3), 411- 423. doi: 10.1037/00332909.103.3.411

Ayalew, M. M. (2020). Bayesian hierarchical analyses for entrepreneurial intention of students. Journal of Big Data, 7(1), 1-23. doi:10.1186/s40537020-00293-x 
Bagozzi, R. P., \& Yi, Y. (1988). On the evaluation of structural equation models. Journal of the Academy of Marketing Science, 16(1), 74-94. doi: $10.1007 / \mathrm{BF} 02723327$

Basu, A., \& Virick, M. (2007). Assessing entrepreneurial intentions amongst students: A comparative study. 12th Annual Meeting of the National Collegiate Inventors and Innovators Alliance (pp. 79-86), Dallas, USA. Retrieved June 2, 2019, from https://www.researchgate.net/ profile/Anuradha_Basu/publication/255583956_ Assessing_Entrepreneurial_Intentions_ Amongst_Students_A_Comparative_Study/ links/5411ffb10cf2fa878ad394f0.pdf

Bates, T. (1995). Self-employment entry across industry groups. Journal of Business Venturing, 10(2), 143-156. doi: 10.1016/08839026(94)00018-P

Bergh, P., Thorgren, S., \& Wincent, J. (2011). Entrepreneurs learning together: The importance of building trust for learning and exploiting business opportunities. International Entrepreneurship and Management Journal, 7(1), 17-37. doi: 10.1007/s11365-0090120-9

Bird, B. (1988). Implementing entrepreneurial ideas: The case for intention. Academy of Management Review, 13(3), 442-453. doi:10.2307/258091

Bolaños, R. (2006). Impacto del modelo a imitar en la intención de crear una empresa [Impact of the model to be imitated on the intention to create a company]. Estudios de Economía Aplicada, 24, 491-508.

Botsaris, C. A., \& Vamvaka, V. (2012). Models of the determinants of entrepreneurial behaviour: A literature review. Regional Science Inquiry, 4(3), 155-172.

Carayannis, E. G., Evans, D., \& Hanson, M. (2003). A cross-cultural learning strategy for entrepreneurship education: Outline of key concepts and lessons learned from a comparative study of entrepreneurship students in France and the US. Technovation, 23(9), 757-771. doi: 10.1016/S0166-4972(02)00030-5

Cefis, E., \& Marsili, O. (2011). Born to flip: Exit decisions of entrepreneurial firms in high-tech and low-tech industries. Journal of Evolutionary Economics, 21(3), 473-498. doi: 10.1007/ s00191-010-0210-4

Chorlton, K., Conner, M., \& Jamson, S. (2012). Identifying the psychological determinants of risky riding: An application of an extended Theory of Planned Behaviour. Accident, Analysis and Prevention, 49, 142-53. doi:10.1016/j. aap.2011.07.003

Díez-Echavarría, L., Valencia-Arias, A., \& BermúdezHernández, J. (2020). Tool for measuring the influence of the field of knowledge on entrepreneurial intention among university students. Periodica Polytechnica Social and Management Sciences, 28(1), 38-47. doi: 10.3311/PPso. 12873

Díez-Echavarría, L., Valencia-Arias, A. A., BermúdezHernández, J., Orlando, M. P. F., Lucelly, U. M. M., \& Adolfo, T. V. J. (2019). Extension of the systemic entrepreneurship intention model in university students. Serbian Journal of Management, 14(2), 277-297. doi:10.5937/ sjm14-17336

Duong, C. D., Nguyen, H. X., Ngo, T. V. N., Nguyen, V. H., \& Nguyen, T. P. L. (2020). The impact of individual and environmental characteristics on students' entrepreneurial intention. Management Science Letters, 10(3), 599-608. doi:10.5267/j. ms1.2019.9.020

Echeverri-Sánchez, L., Valencia-Arias, A., BenjumeaArias, M., \& Toro, A. B. D. (2018). Factores que inciden en la intención emprendedora del estudiantado universitario: Un análisis cualitativo [Factors that affect the entrepreneurial 
intention of university students: A qualitative analysis]. Revista Electronica Educare, 22(2), 160-178. doi: 10.15359/ree.22-2.10

Erikson, T. (2002). Entrepreneurial capital: The emerging venture's most important asset and competitive advantage. Journal of Business Venturing, 17(3), 275-290. doi: 10.1016/S08839026(00)00062-8

Eyel, C. Ş., \& Durmaz, İ. B. V. (2019). Entrepreneurial intentions of Generation-Z: Compare of social sciences and natural sciences undergraduate students at Bahçeşehir University. Procedia Computer Science, 158, 861-868. doi: 10.1016/j. procs.2019.09.124

Fang, C., \& Chen, L. (2019). Exploring the entrepreneurial intentions of Science and Engineering students in China: AQ methodology study. Sustainability, 11(10), 2751. doi: 10.3390/ su11102751

Fayolle, A., \& Liñán, F. (2014). The future of research on entrepreneurial intentions. Journal of Business Research, 67(5), 663-666. doi:10.1016/j. jbusres.2013.11.024.

Fornell, C., \& Larcker, D. F. (1981). Structural equation models with unobservable variables and measurement error: Algebra and statistics. Journal of Marketing Research, 18(3), 382-388. doi:10.2307/3150980

Gailly, B., \& Fayolle, A. (2004). Using the theory of planned behaviour to assess entrepreneurship teaching programs: A First Experimentation. The 4th Annual IntEnt Conference. Naples, Italy: University of Napoli Federico II.

Galleguillos-Cortés, C., Escobar-Burgos, B., \& Hurtado-Cailly, R. (2019). Predictores de la intención emprendedora en alumnos de pregrado: Un modelo basado en ecuaciones estructurales [Predictors of entrepreneurial intention in undergraduate students: A model based on structural equations]. Formación
Universitaria, 12(1), 83-94. doi: 10.4067/S071850062019000100083

Guzmán, C., \& Guzmán, J. (2012). Entrepreneurial intention models as applied to Latin America. Journal of Organizational Change Management, 25(5), 721-735. doi: $10.1108 / 09534811211254608$

Hair, J. F., Black, W. C., Babin, B. J., \& Anderson, R. E. (2010). Multivariate data analysis. Englewood Cliffs, USA: Prentice Hall.

Hattab, H. W. (2014). Impact of entrepreneurship education on entrepreneurial intentions of university students in Egypt. The Journal of Entrepreneurship, 23(1), 1-18. doi:10.1177/0971355713513346

Hernández-López, D. M., Moncada-Toro, J. F., \& Henao-Colorado, L. C. (2018). Intención emprendedora de los empleados del sector privado de la ciudad de medellín y su área metropolitana [Entrepreneurial intention of employees in the private sector in medellín and its metropolitan área]. Revista CEA, 4(8), 13-33. doi: 10.22430/24223182.1045

Herrington, M., Kew, J., Simre, M., \& Turton, N. (2011). Global entreprenurship monitor South Africa. Cape Town, South Africa: University of Cape Town.

Hirsch, A., \& Pérez, J. (2005). Actitudes y ética profesional en estudiantes de posgrado en la Universidad de Valencia y la UNAM [Attitudes and professional ethics in graduate students at the University of Valencia and UNAM]. Reencuentro, 43, 2-11.

Hu, L. T., \& Bentler, P. M. (1999). Cutoff criteria for fit indexes in covariance structure analysis: Conventional criteria versus new alternatives. Structural Equation Modeling: A Multidisciplinary Journal, 6(1), 1-55. doi: 10.1080/10705519909540118 
Iakovleva, T., \& Kolvereid, L. (2009). An integrated model of entrepreneurial intentions. International Journal of Business and Globalisation, 3(1), 6680. doi:10.1504/ijbg.2009.021632

Ismail, V. Y., \& Zain, E. (2015). The portrait of entrepreneurial competence on student entrepreneur https://doi.org/10.1016/j. sbspro.2015.01.300s. Procedia-Social and Behavioral Sciences, 169, 178-188.

Kolvereid, L. (1996). Prediction of employment status choice intentions. Entrepreneurship Theory \& Practice, 21(1), 47-57. doi: $10.1177 / 104225879602100104$

Krueger Jr, N. F., Reilly, M. D., \& Carsrud, A. L. (2000). Competing models of entrepreneurial intentions. Journal of Business Venturing, 15(56), 411-432. doi: 10.1016/S0883-9026(98)000330

Krueger, N. F., \& Carsrud, A. (1993). Entrepreneurial intentions: Applying the theory of planned behaviour. Entrepreneurship \& Regional Development, 5(4), 315-330. doi:10.1080/08985629300000020

Lechuga, M. P., Martín-Navarro, A., \& RamosRodríguez, A. R. (2020). Will they end up doing what they like? The moderating role of the attitude towards entrepreneurship in the formation of entrepreneurial intentions. Studies in Higher Education, 45(2), 416-433. doi:10.10 80/03075079.2018.1539959

Lee, S. H., \& Wong, P. K. (2004). An exploratory study of technopreneurial intentions: A career anchor perspective. Journal of Business Venturing, 19(1), 7-28. doi: 10.1016/S08839026(02)00112-X

Lee, S. M., Lim, S. B., \& Pathak, R. D. (2011). Culture and entrepreneurial orientation: A multi-country study. International Entrepreneurship and Management Journal, 7(1), 1-15. doi: 10.1007/ s11365-009-0117-4
Lichtenstein, B. (2016). Emergence and emergents in entrepreneurship: Complexity science insights into new venture creation. Entrepreneurship Research Journal, 6(1), 43-52. doi: 10.1515/ erj-2015-0052

Lien, N., Lytle, L., \& Komro, K. (2002). Applying theory of planned behaviour to fruit consumption of young adolescents. American Journal of Health Promotion, 16, 189-197. doi: 10.4278/08901171-16.4.189

Liñán, F. (2008). Skill and value perceptions: How do they affect entrepreneurial intentions? International Entrepreneurship and Management Journal, 4(3), 257-272. doi: 10.1007/s11365008-0093-0

Liñán, F., \& Chen, Y. W. (2009). Development and cross-cultural application of a specific instrument to measure entrepreneurial intentions. Entrepreneurship: Theory and Practice, 33(3), 593-617. doi: 10.1111/j.1540-6520.2009.00318.x

Liñán, F., Urbano, D., \& Guerrero, M. (2011). Regional variations in entrepreneurial cognitions: Start-up intentions of university students in Spain. Entrepreneurship and Regional Development, 23(3-4), 187-215. doi: 10.1080/08985620903233929

Marcati, A., Guido, G., \& Peluso, A. M. (2008). The role of SME entrepreneurs' innovativeness and personality in the adoption of innovations. Research Policy, 37(9), 1579-1590. doi:10.1016/j. respol.2008.06.004

Marcketti, S. B., Niehm, L. S., \& Fuloria, R. (2006). An exploratory study of lifestyle entrepreneurship and its relationship to life quality. Family and Consumer Sciences Research Journal, 34(3), 241-259. doi:10.1177/1077727X05283632

Marques, C. S., Ferreira, J. J., Gomes, D. N., \& Rodrigues, R. G. (2012). Entrepreneurship education: How psychological, demographic and behavioural factors predict the entrepreneurial 
intention. Education + Training, 54(8/9), 657672. doi: 10.1108/00400911211274819

Moriano, J., Gorgievski, M., Laguna, M., Ute, S., \& Zarafshani, K. (2011). Understanding entrepreneurial intention. Journal of Career Development, 1-32.

Munir, H., Jianfeng, C., \& Ramzan, S. (2019). Personality traits and theory of planned behavior comparison of entrepreneurial intentions between an emerging economy and a developing country. International Journal of Entrepreneurial Behavior \& Research, 25(3), 554-580. doi:10.1108/IJEBR-05-2018-0336

Naktiyok, A., Karabey, C. N., \& Gulluce, A. C. (2010). Entrepreneurial self-efficacy and entrepreneurial intention: The Turkish case. International Entrepreneurship and Management Journal, 6(4), 419-435. doi: 10.1007/s11365-009-0123-6

Nueno, P. (1994). El arte de crear empresas y sus artistas [The art of creating companies and their artists]. Madrid, Spain: Publicado por Deusto.

Nunnally, J. C., \& Bernstein, I. H. (1994). Psychometric theory (3rd ed.). New York, USA: McGraw-Hill.

Ordoñez, J. P. M., Marín, C. M. A., \& Sánchez, L. C. E. (2017). El papel de la educación en creación de empresas en el contexto universitario a partir de los estudios registrados en Scopus [The role of education in business creation in the university context from the studies registered in Scopus]. Revista CEA, 3(5), 69-87. doi:10.22430/24223182.651

Pee, L. G., Woon, I. M. Y., \& Kankanhalli, A. (2008). Explaining non-work-related computing in the workplace: A comparison of alternative models. Information \& Management, 45(2), 120-130. doi:10.1016/j.im.2008.01.004

Peterman, N. E., \& Kennedy, J. (2003). Enterprise education: Influencing students' perceptions of entrepreneurship. Entrepreneurship Theory and
Practice, 28(2), 129-144. doi: 10.1046/j.15406520.2003.00035.x

Pulgarin, S., \& Cardona, D. (2016) Hacia un modelo explicativo del proceso innovador para centros de emprendimiento: Una aproximación desde las exaptaciones y la diversidad [Towards an explanatory model of the innovative process for entrepreneurship centers: An approach from exaptations and diversity]. In I. Montoya, A. Montoya, \& A. Valencia-Arias (Eds.), Metáforas biológicas aplicadas a las organizaciones [Biological metaphors applied to organizations] (2nd ed., pp. 11-48). Bogotá, Colombia: CID/ UNAL.

Rae, D. (2010). Universities and enterprise education: Responding to the challenges of the new era. Journal of Small Business and Enterprise Development, 17(4), 591-606. doi: $10.1108 / 14626001011088741$

Rosseel, Y. (2012). Lavaan: An R package for structural equation modeling and more. Version 0.5-12 (BETA). Journal of Statistical Software, 48(2), 1-36. doi:10.18637/jss.v048.i02

Schmutzler, J., Andonova, V., \& Diaz-Serrano, L. (2019). How context shapes entrepreneurial selfefficacy as a driver of entrepreneurial intentions: A multilevel approach. Entrepreneurship Theory and Practice, 43(5), 880-920. doi: $10.1177 / 1042258717753142$

Sebora, T. C., \& Theerapatvong, T. (2010). Corporate entrepreneurship: A test of external and internal influences on managers' idea generation, risk taking, and proactiveness. International Entrepreneurship and Management Journal, 6(3), 331-350. doi:10.1007/s11365009-0108-5

Segal, G., Borgia, D., \& Schoenfeld, J. (2005). The motivation to become an entrepreneur. International Journal of Entrepreneurial Behaviour \& Research, 11(1), 42-57. doi: $10.1108 / 13552550510580834$ 
Shamsudin, S. F. F. B., Mamun, A. A., Nawi, N. B. C., Nasir, N. A. B. M., \& Zakaria, M. N. B. (2017). Factors influencing entrepreneurial intention and the moderating role of entrepreneurship education: A conceptual model. Advanced Science Letters, 23(4), 3006-3008. doi: 10.1166/ asl.2017.7635

Shepherd, D. A., Williams, T. A., \& Patzelt, H. (2015). Thinking about entrepreneurial decision making: Review and research agenda. Journal of Management, 41(1), 11-46. doi: $10.1177 / 0149206314541153$

Sondari, M. C. (2014). Is entrepreneurship education really needed?: Examining the antecedent of entrepreneurial career intention. ProcediaSocial and Behavioral Sciences, 115, 44-53. doi: 10.1016/j.sbspro.2014.02.414

Song, M., Podoynitsyna, K., Van Der Bij, H., \& Halman, J. I. (2008). Success factors in new ventures: A meta-analysis. Journal of Product Innovation Management, 25(1), 7-27. doi: 10.1111/j.1540-5885.2007.00280.x

Soria, K., Zuniga-Jara, S., \& Ruiz, S. (2016). Educación e intención emprendedora en estudiantes universitarios: Un caso de estudio [Education and entrepreneurial intention in university students: A case study]. Formación Universitaria, 9(1), 25-34. doi: 10.4067/S071850062016000100004

Souitaris, V., Zerbinati, S., \& Al-Laham, A. (2007). Do entrepreneurship programmes raise entrepreneurial intention of science and engineering students? The effect of learning, inspiration and resources. Journal of Business Venturing, 22(4), 566-591. doi:10.1016/j. jbusvent.2006.05.002.

Suárez, A., García, N., \& Álvarez, M. (2009). La interactividad en cuestionarios autoadministrados. Influencia en la experiencia del encuestado [Interactivity in self-administered questionnaires. Influence on the respondent's experience]. Cuadernos de Economía y Dirección de la Empresa, 41, 69-92. doi: 10.1016/S11385758(09)70048-9.

Tarkiainen, A., \& Sundqvist, S. (2005). Subjective norms, attitudes and intentions of Finnish consumers in buying organic food. British Food Journal, 107(11), 808-822. doi: $10.1108 / 00070700510629760$

The R Core Team. (2016). R: A language and environment for statistical computing (3.3.1 ed.). Vienna, Austria: R Foundation for Statistical Computing.

Torres, J. A., Valencia, A., Bermúdez, J., DíezEchavarría, L. F., Urrego, M. L. \& Maussa, F. O. (2018). Characterization of entrepreneurial intention in university students as from Systemic Entrepreneurship Intention Model: A case study. Cuadernos de Gestión, 18(2), 1-17. doi:10.5295/ cdg.160670jt

Tshikovhi, N., \& Shambare, R. (2015). Entrepreneurial knowledge, personal attitudes, and entrepreneurship intentions among South African Enactus students. Problems and Perspectives in Management, 13(1), 152-158.

Vamvaka, V., Stoforos, C., Palaskas, T., \& Botsaris, C. (2020). Attitude toward entrepreneurship, perceived behavioral control, and entrepreneurial intention: dimensionality, structural relationships, and gender differences. Journal of Innovation and Entrepreneurship, 9, 5. doi: 10.1186/s13731020-0112-0

van Dam, K., Schipper, M., \& Runhaar, P. (2010). Developing a competency-based framework for teachers' entrepreneurial behaviour. Teaching and Teacher Education, 26(4), 965-971. doi: 10.1016/j.tate.2009.10.038

van Gelderen, M., Kautonen, T., \& Fink, M. (2015). From entrepreneurial intentions to actions: Self-control and action-related doubt, fear, and aversion. Journal of Business Venturing, 30(5), 655-673. doi: 10.1016/j.jbusvent.2015.01.003 
van Riel, A. C., Semeijn, J., Hammedi, W., \& Henseler, J. (2011). Technology-based service proposal screening and decision-making effectiveness. Management Decision, 49(5), 762-783. doi: 10.1108/00251741111130841

Veciana, J. M. (1999). Creación de empresas como programa de investigación científica [Business creation as a scientific research program]. Revista Europea de Dirección y Economía de la Empresa, 8(3), 11-36.
Vergés, J., Guallarte, C., Capelleras, J. L., Urbano, D., \& Genescà, E. (2003). Creación de empresas [Business creation] (33rd ed.). Barcelona, Spain: Universitat Autònoma de Barcelona, Servei de Publicacions.

Zeng, F. Q., Bu, X. Z., \& Su, L. (2011). Study on entrepreneurial process model for SIFE student team based on Timmons model. Journal of Chinese Entrepreneurship, 3(3), 204-214. doi: $10.1108 / 17561391111166984$ 


\section{APPENDIX 1}

\section{Questionnaire}

\begin{tabular}{ll}
\hline Subjective norms & $\begin{array}{l}\text { How much do you care about what your closest relatives think of your } \\
\text { decision to pursue an entrepreneurial career or not? } \\
\text { How much do you care about what your closest friends think of your } \\
\text { decision to pursue an entrepreneurial career or not? } \\
\text { How much do you care about what people who are important to you } \\
\text { think of your decision to pursue an entrepreneurial career or not? }\end{array}$ \\
\hline $\begin{array}{l}\text { Normative } \\
\text { beliefs }\end{array}$ & My closest relatives think I should pursue an entrepreneurial career. \\
& My closest friends think I should pursue an entrepreneurial career. \\
& $\begin{array}{l}\text { People who are important to me think I should pursue an } \\
\text { entrepreneurial career. }\end{array}$ \\
\hline $\begin{array}{l}\text { Entrepreneurial } \\
\text { intention }\end{array}$ & $\begin{array}{l}\text { I will do everything I can to start and run my own business. } \\
\text { I am decided to start a business in the future. }\end{array}$ \\
& My professional objective is to be an entrepreneur. \\
\hline $\begin{array}{l}\text { Behavioral } \\
\text { beliefs }\end{array}$ & Entrepreneurs can improve their work-life balance. \\
& Entrepreneurship is full of challenges. \\
& Entrepreneurs have a good life.
\end{tabular}

Entrepreneurial I can take action to find opportunities.

behavior

I can see new market opportunities for new products and services.

I can establish and maintain positive relationships with potential investors.

Personal attitude To me, being an entrepreneur entails more advantages than disadvantages.

Being an entrepreneur would give me great satisfaction.

Becoming an entrepreneur is appealing to me. 